Prepared for the U.S. Department of Energy

Under Contract DE-AC05-76RL01830

\title{
Climate Change Vulnerability and Resilience: Current Status and Trends for Mexico
}

ME Ibarrarán

EL Malone

AL Brenkert

December 2008

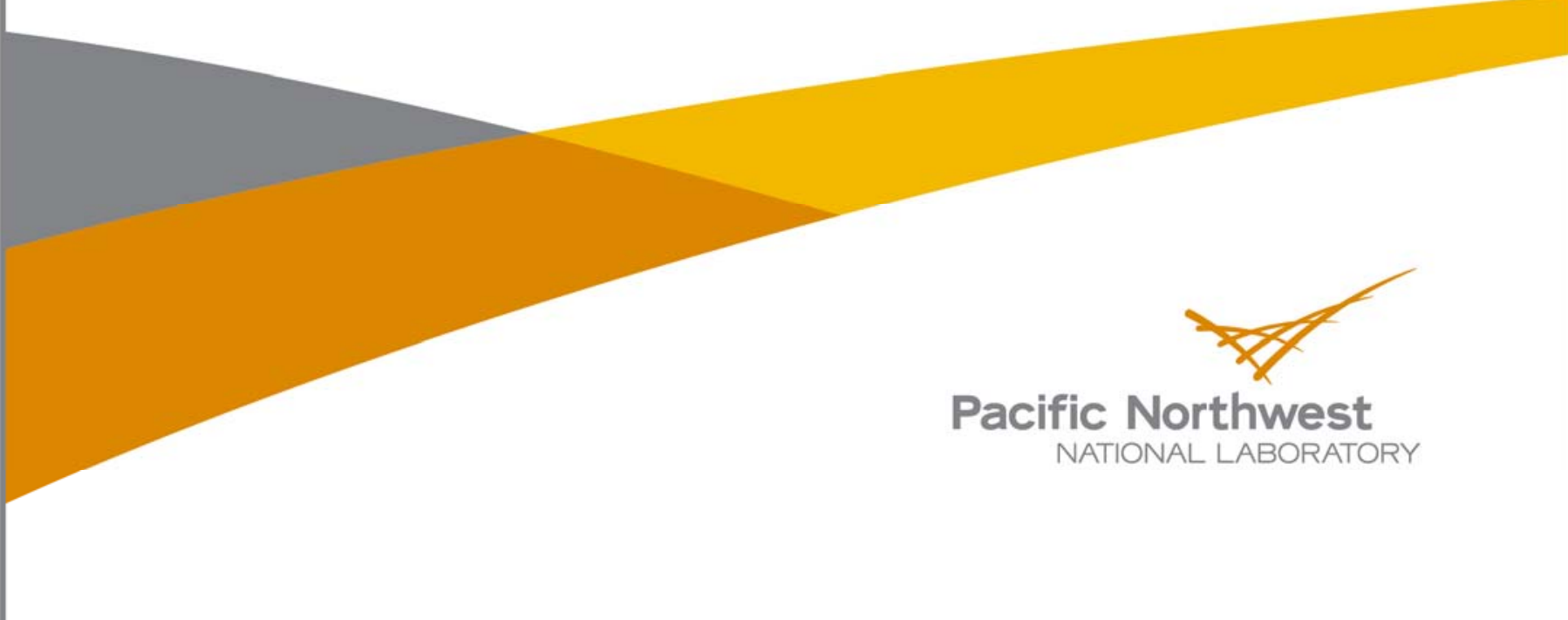




\title{
DISCLAIMER
}

This report was prepared as an account of work sponsored by an agency of the United States Government. Neither the United States Government nor any agency thereof, nor Battelle Memorial Institute, nor any of their employees, makes any warranty, express or implied, or assumes any legal liability or responsibility for the accuracy, completeness, or usefulness of any information, apparatus, product, or process disclosed, or represents that its use would not infringe privately owned rights. Reference herein to any specific commercial product, process, or service by trade name, trademark, manufacturer, or otherwise does not necessarily constitute or imply its endorsement, recommendation, or favoring by the United States Government or any agency thereof, or Battelle Memorial Institute. The views and opinions of authors expressed herein do not necessarily state or reflect those of the United States Government or any agency thereof.

\author{
PACIFIC NORTHWEST NATIONAL LABORATORY \\ operated by \\ BATTELLE \\ for the \\ UNITED STATES DEPARTMENT OF ENERGY \\ under Contract DE-AC05-76RL01830
}

Printed in the United States of America
Available to DOE and DOE contractors from the Office of Scientific and Technical Information,
P.O. Box 62, Oak Ridge, TN 37831-0062;
ph: (865) 576-8401
fax: $(865) 576-5728$
email: reports@adonis.osti.gov

\footnotetext{
Available to the public from the National Technical Information Service, U.S. Department of Commerce, 5285 Port Royal Rd., Springfield, VA 22161 ph: (800) 553-6847 fax: $(703) 605-6900$ email: orders@ntis.fedworld.gov online ordering: http://www.ntis.gov/ordering.htm
}

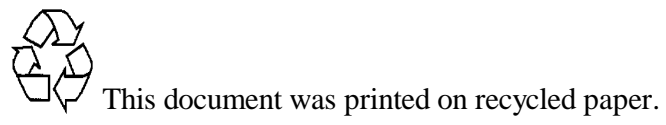




\title{
Climate Change Vulnerability and Resilience: Current Status and Trends for Mexico
}

\author{
ME Ibarrarán \\ AL Brenkert \\ EL Malone
}

December 2008

Prepared for the U.S. Department of Energy

under Contract DE-AC05-76RL01830

Pacific Northwest National Laboratory

Richland, Washington 99352 


\begin{abstract}
Climate change alters different localities on the planet in different ways. The impact on each region depends mainly on the degree of vulnerability that natural ecosystems and human-made infrastructure have to changes in climate and extreme meteorological events, as well as on the coping and adaptation capacity towards new environmental conditions. This study assesses the current resilience of Mexico and Mexican states to such changes, as well as how this resilience will look in the future.

In recent studies (Moss et al. 2000, Brenkert and Malone 2005, Malone and Brenket 2008, Ibarrarán et al. 2007), the Vulnerability-Resilience Indicators Model (VRIM) is used to integrate a set of proxy variables that determine the resilience of a region to climate change. Resilience, or the ability of a region to respond to climate variations and natural events that result from climate change, is given by its adaptation and coping capacity and its sensitivity. On the one hand, the sensitivity of a region to climate change is assessed, emphasizing its infrastructure, food security, water resources, and the health of the population and regional ecosystems. On the other hand, coping and adaptation capacity is based on the availability of human resources, economic capacity and environmental capacity.
\end{abstract}

This paper presents two sets of results. First we show the application of the VRIM to determine statelevel resilience for Mexico, building the baseline that reflects the current status. The second part of the paper makes projections of resilience under socioeconomic and climate change and examines the varying sources and consequences of those changes. We used three tools to examine Mexico's resilience in the face of climate change, i.e., the baseline calculations regarding resilience indices made by the VRIM, the projected short-term rates of socioeconomic change from the Boyd-Ibarrarán computable general equilibrium model, and rates of the IPCC-SRES scenario projections from the integrated assessment MiniCAM model. This allows us to have available change rates for VRIM variables through the end of the $21^{\text {st }}$ century.

Keywords: Climate change, Mexico, Model Projections, Adaptive Capacity, Resilience, Vulnerability 


\section{Contents}

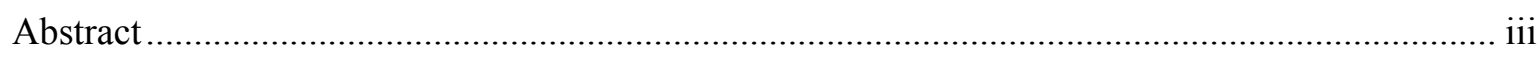

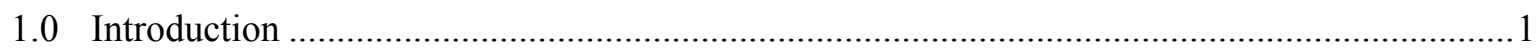

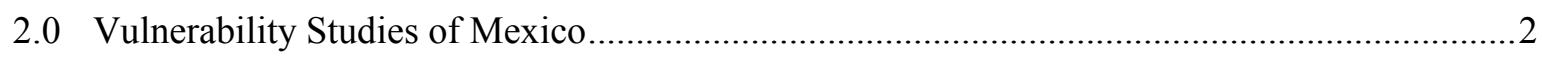

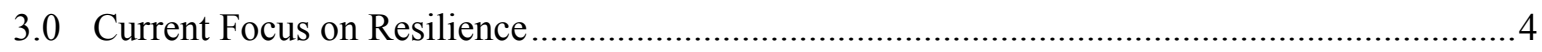

4.0 Modeling Baseline Resilience for Mexico and Mexican States .............................................5

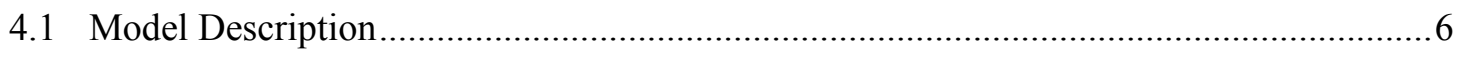

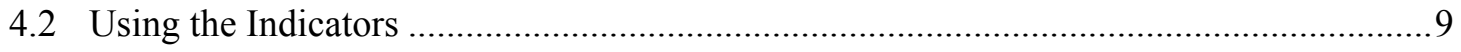

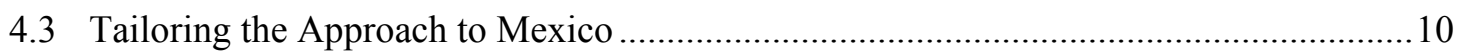

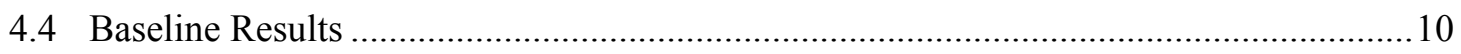

5.0 Methods for Projecting Resilience in Mexico ................................................................... 13

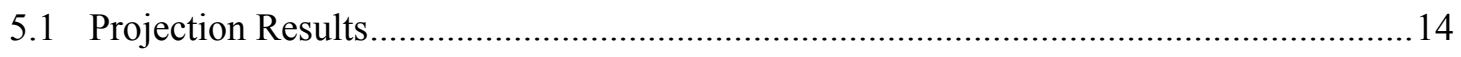

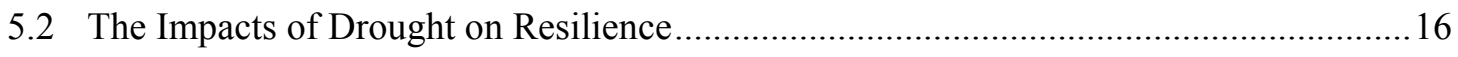

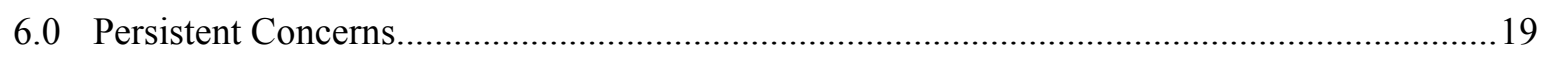

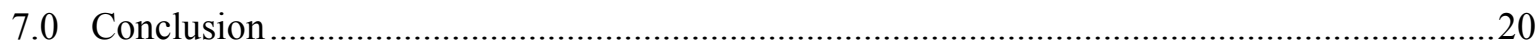

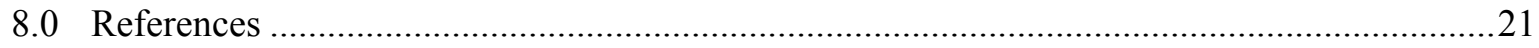




\subsection{Introduction}

In the past few years and especially since the publication of the Intergovernmental Panel on Climate Change's (IPCC's) Fourth Assessment Report in 2007, attention has shifted from the question, "Is climate change real?" to the questions, "How severe will the changes be?" and "How can societies both mitigate change and build adaptive capacity?" These shifts in attention bring into focus rich veins of scientific research on the vulnerabilities of specific places, the potential for climate-related disasters and disaster responses, and strategies to prepare for climate change impacts. What these research foci have in common is that they are centered in analysis of human welfare rather than the physics or chemistry of the climate. They consequently open up the realm of decision-making beyond recommendations on the technical feasibility of various policy options - to a consideration of overall societal development in the context of economic, political, and cultural conditions.

Studies of societal vulnerabilities, resilience, and adaptive capacity have both added to the knowledge base and provided new tools for such analyses. Much of the existing literature on these topics is in the forms of case studies of particular societies and sectoral studies, notably in agriculture. Although these are extremely valuable in the particular contexts of their research objects, the IPCC has, since its Second Assessment Report, identified two important challenges in its impact assessments (Watson et al. 1996, 1998, McCarthy et al. 2001): to improve approaches for comparing and aggregating impacts across diverse sectors and populations and to model socioeconomic transformations as well as climate change in assessing the future significance of climate change.

Inevitably, comparative studies sacrifice the valuable details of case studies in favor of a necessarily sparse set of data that is available for all the units of analysis. This allows the 10,000-meter view of places that can be compared and begins to map out the variability of both vulnerability and resiliencebut such an analysis cannot replace a closer look at specific aspects that must be the basis for decision making.

Moreover, quantification and modeling are desirable but subject to the same issues that confront energyeconomic integrated assessment (IA) models: the dependence on several levels of assumptions, possible lack of important variables, co-linearity, lack of accounting for interactions/feedbacks, and so on (Parson and Fisher-Vanden 1997).

Nevertheless, vulnerability and resilience assessments point the way to an integrated model that can provide potential insights and guidance in the areas of impacts, adaptation, and societal behavior. The model used for this study, the Vulnerability and Resilience Indicators Model (VRIM) is a nascent approach to meeting this objective.

This paper connects the likely impacts of climate change and Mexico's resilience to it - that is, the extent to which Mexico and its states have the capability to maintain the livelihoods and well-being of their citizens as they are exposed to warmer temperatures, more and more severe climate events (especially droughts), and sea level rise. We first discuss our emphasis on resilience (rather than on vulnerability) and the advantages of doing so, then outline the methodology for our comparative analysis of resilience at the country and state levels. We describe our model and the indicators used to comparatively assess resilience at the country and state levels. The model results show differences in levels and sources of resilience; two-state comparisons provide further insight about differences among states, suggesting differentiating strategies will be important in building resilience. 


\subsection{Vulnerability Studies of Mexico}

When impacts research began to expand beyond estimates of damages to agriculture, coastal areas, and the like, the initial focus was on vulnerability. In the case of Mexico, there has been a vast amount of research addressing vulnerability, mainly from a biophysical and sociological point of view.

Blaikie et al. (1996) propose a new approach to vulnerability that takes into account the social, economic and political environment of disasters. The analytical model, the Pressure and Release (PAR) model, examines the evolution of unsafe conditions, specifically dynamic pressures such as urbanization and environmental degradation, and the origin of their causes and background explained by the political economy. This model incorporates the temporal dimension, the disruption not just of the lives and property but also of livelihoods, and the difficulty of rebuilding again in the future. Against the physicalist vision that disasters are caused directly by events or physical threats, Blaikie et al. claim that a disaster occurs when unsafe conditions in the social system converge with a natural hazard, i.e., when a considerable number of people experience a hazard and suffer serious damage and/or disruption of their subsistence system, such that recovery is unlikely without outside help.

Several studies examine vulnerability within this framework. For example, Florescano (1980) states that "the most disastrous effects of drought, as in the earlier times, are concentrated in the rain-fed agriculture practiced by the poorest ejidatarios and campesinos, lacking credit, irrigation, fertilizers, and improved seeds."

On the other hand, Liverman $(1990,1994)$ defines natural hazard vulnerability "as the characteristics of places or people that are likely to be harmed by meteorological and geophysical events" and adds that "Mexico has become more vulnerable to drought in recent years" because of the expansion of commercial agriculture and land reform, which create groups of poor rural dwellers with limited and insecure access to land resources. Throughout her analysis, she focuses mostly on drought and mentions pregnant women, children, elderly, the poor, and the ones who live in areas of high hazard as the most vulnerable to natural disaster. She also states that technology does not always reduce biophysical vulnerability. Irrigation, variety of improved seeds, and fertilizers can reduce vulnerability, but technology also replaces traditional hazard prevention strategies such as mixed cropping and expands agriculture into areas of high hazard risk such as mountains, coastal regions, and disease-susceptible humid tropics. This often translates into dependency on foreign imports and further environmental degradation. So landlessness, poor soils, and political weakness, mixed with inappropriate technologies, make some people more vulnerable to drought than others. The conditions and variables are divided into six groups: environment, technology, social relations, demographics and health, land use and ownership, and economy and institutions.

Eakin et al. (2007) look at social vulnerability of farmers in Mexico (and in Argentina), and find that their main source of vulnerability is the trend toward large, single-product farm units. In addition, in the case of Mexico, the lack of income diversification and access to financial and material resources increases their sensitivity and lowers their adaptation capacity, since they do not have a buffer against climatic risk.

García Acosta (coord.) (2005) argues that there is a social construction of a disaster, caused basically by poverty, exclusion, the lack of urban planning and corruption. Preexisting vulnerability conditions cause risk, and natural phenomena increase these vulnerabilities to extremes when disasters occur. 
Vera (2005) adopts the definition posed by Blakie et al. (1996) that social vulnerability is defined as the capacity to have access to resources, both to cover basic needs as well as to allow for decision making and economic and political participation. To understand vulnerability, risk, and disaster, the study should look at multiple causes, including the existence of cacicazgos (or individuals with strong local economic power and leadership), land concentration, land degradation (due to deforestation and erosion) and an unequal distribution of resources among regions, where low productivity regions receive less than those with high productivity. In addition, regions may lack services related to health, water, energy and education, with a predominantly rural population experiencing malnutrition, profound poverty and income distribution issues, migration to new touristic complexes and abandonment of their land, and disparities in the sharing of assistance due to political fragmentation. However, Vera foresees that the affected populations may learn from their experience and mitigate their vulnerability. Thus, disasters may be an opportunity for change.

Villegas (2005) perceives disaster as a social process resulting from the extreme expression of two produced and reproduced social conditions: risk and vulnerability. She therefore analyzes the social conditions under which vulnerability is produced, following Hewitt (1993), who argues that disasters are the impact of extreme geophysical events on a passive population.

More in the line of urban vulnerability, Satterthwaite et al. (2007) understand vulnerability to climate change as the potential of people to be killed, injured or otherwise harmed by the direct or indirect impacts of climate change. Particularly, urban vulnerability is seen as the result of weak governments and poverty, a more frequent situation in low-and middle-income nations where people have limited resources and infrastructure to resist an event caused by climate change. The researchers mention several studies of urban vulnerability, where Mexico is included in the broader case of Latin America and the Caribbean.

García Avila (2007) defines vulnerability as the process by which human population and ecosystems are subject to damage or threat due to social and biophysical factors. Water itself can be one factor of vulnerability. She looks at 11 types of water-related vulnerabilities, making an assessment of the status of 13 different hydrologic regions of Mexico (according to the National Comission of Water (Comisión Nacional del Agua, CNA)).

Sánchez (2008) looks at how the effects of human behavior and interaction, consumption, land use and land cover change, climate change, and population growth increases vulnerability in an area. He argues that "the biggest challenge for a broader global environmental change perspective on cities is the creation of new conceptual frameworks and methodologies to study these issues" (Sánchez, 2002). He also addresses sustainability, decentralization, and public policies as factors to reduce vulnerability in urban areas, and discusses the consequences to an area that does not consider these components. 


\subsection{Current Focus on Resilience}

As in most of the studies discussed above, vulnerability is often connected with research on natural disasters. Climate change, while it may encompass more severe weather-related disasters, has other impacts of a more gradual nature. In this way, the concept of vulnerability offers only a narrow lens of analysis. Moreover, vulnerability is a deficit concept; researchers and analysts are examining what is wrong, with at least an implicit conclusion that these vulnerability-contributing factors need correction. Such an approach contains sign problems for those who might use the research to help improve conditions for affected people and to design adaptation activities. Using vulnerability studies, decisionmakers must keep in mind that, while high values of many attributes are good (high income, test scores), high vulnerability is actually bad, so instead of trying to raise low values, the recommendations have the effect of suggesting that decision-makers work on lowering high scores.

To address these concerns about vulnerability, we focus on the concept of resilience. Resilience has a robust history in ecology, beginning with Holling (1973); Folke (2006) describes the evolution of the term in ecology and in social-ecological systems analysis. The term's meaning has evolved over time. Originally, resilience most often meant a return to a previous state. A perturbation hit a system and (quickly or gradually) it went back to its original condition. Subsequent work, both on ecosystems and societies, has identified the potential for multiple equilibria and the possibility of successfully adapting to changed circumstances by developing a new state. Thus, resilience includes both an element of recovery and an element of change. Moreover, it is a positive concept; high "scores" are good and factors like air pollution and lack of education are negatives. This makes intuitive sense as the results of an assessment are discussed.

And, resilience is not simply the inverse of vulnerability, as the IPCC definitions show (Parry et al. 2008, 880 and 882):

Resilience: The ability of a social or ecological system to absorb disturbances while retaining the same basic structure and ways of functioning, the capacity for self-organization, and the capacity to adapt to stress and change.

Vulnerability is the degree to which a system is susceptible to, and unable to cope with, adverse effects of climate change, including climate variability of extremes. Vulnerability is a function of the character, magnitude, and rate of climate change and variation to which a system is exposed, its sensitivity, and its adaptive capacity.

The VRIM, like the definition of resilience, focuses on adaptive capacity, balanced by the sensitivity of human and ecological systems, without including a climate change term (except to exposure to storm surges), as the definition of vulnerability does. 


\subsection{Modeling Baseline Resilience for Mexico and Mexican States}

To evaluate the extent and sources of Mexican resilience to climate variability and change, we use a comparative, quantitative framework, the VRIM. The VRIM was developed specifically to integrate socioeconomic and environmental information and provide this quantitative comparative basis for assessing resilience.

Even though, as discussed above, there is a vast amount of qualitative work in Mexico (and abroad) on vulnerability, there is a definite need to measure the relative resilience among places. This is the objective of this paper. There are many international efforts to compute such indexes, as described below (Moss et al., 2000; Brenket and Malone 2005, Brooks et al. 2005, Cutter et al. 2003, and Pratschke y Haase (2000), to name a few). However, this has not been done for Mexico.

An index may be computed using any of several methodologies. Here we present three alternatives used in the literature. One uses factor analysis approach, another expert judgment and econometrics, and a third econometrics.

Cutter et al. (2003) create an index of social vulnerability to environmental hazards for the United States at the county level, using 1990 data. They define vulnerability as the potential loss due to social and place inequality. In this paper they analyze social vulnerability (and leave out place-specific vulnerability). Their methodology consists in the use of an un-weighted additive model where variables are selected through principal components. Variables are then normalized, scaled and added to compute a summary score. (For other examples of the use of Principal Components Analysis, see Townsend et al. (1988), Carstairs and Morris (1990), and Coombes et al. (1994)).

Brooks et al. (2005), on the other hand, use expert judgment to select a broad range of indicators that explain vulnerability and capacity to adapt to climate change at the national level and on a decadal timescale. Even though national level data makes strong simplifications, it produces valuable information used at the central government level. They define as their outcome variable vulnerability to mortality that results from population exposed to natural hazards through the proportion of the population that died due to climate variability-caused disasters (and by extension to climate change), with respect to total population, and look at what the determinants of this ratio are. Using expert groups, they make a list of over 40 indicators and then through correlation analysis determine 11 key variables at the national level to include into a vulnerability index. Again using expert judgment, they assign weights to the variables used for the index and obtained an average score to produce a composite vulnerability index. Finally, they perform a sensitivity analysis by changing these weights.

In a third type of analysis, in a study of Mexico's Yaqui Valley, Luers et al. (2003) posit a generic vulnerability metric that measures a threshold of damage against the susceptibility of a system's sensitivity to and exposure to stressors. Their threshold metric is the wheat yield of a farm.

The VRIM in our analysis of Mexican states is more downscaled in that it analyzes states instead of nations, as opposed to Brooks et al. (2005), but is more aggregated than Cutter et al. (2003) that looks at counties. The selection of variables is based on a wide-ranging literature review and includes variables that can be measured, even though other more qualitative aspects are being explicitly left out due to measurement issues or to a lack of a clear variable to represent specific concepts, such as in the case of social capital, for instance. 
Although very useful for quantifying the vulnerability of specific variables, the Luers et al. (2003) methodology does not yield the sort of integrated assessment we seek. Moreover, the VRIM-based state-by-state comparisons more closely mimic the processes of policymakers who must make tradeoffs among issues that can and cannot be addressed.

\subsection{Model Description}

The VRIM is a hierarchical model that aggregates a number of proxy values into sectors, which in turn are aggregated into sensitivity and adaptive capacity values, and finally into a vulnerability-resilience index. The first two levels of the structure are shown in Figure 1.

Figure 1. A simplified diagram of the Vulnerability-Resilience Indicators Model (VRIM)

\section{Climate Change \& Variability}

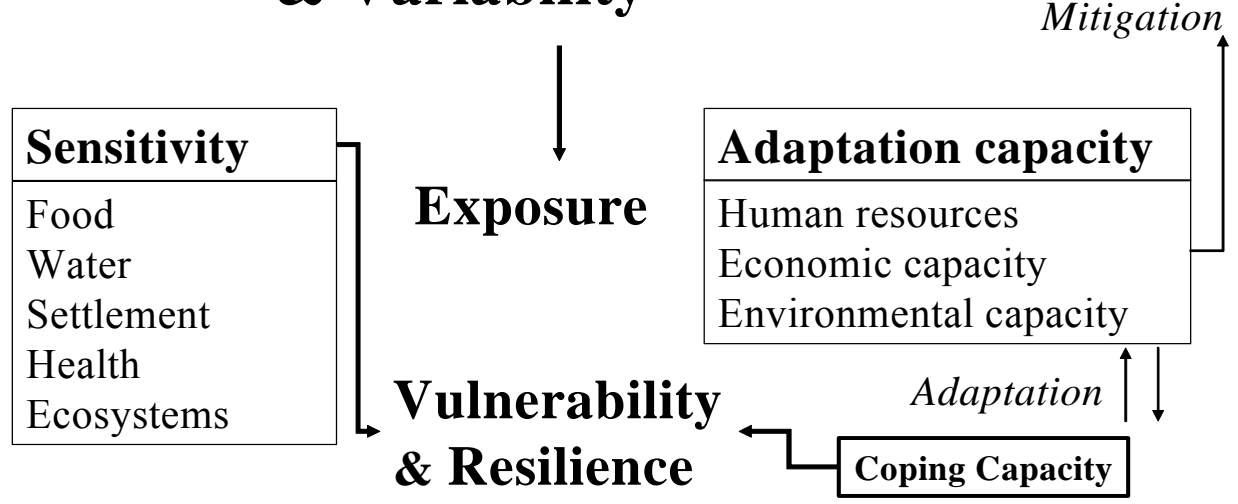

The third level comprises 1-3 proxy variables under each sector; all 18 proxy variables, by sector, are listed in Table 1 (see also Brenkert and Malone 2005), along with a description of what the proxy stands for and how it functions in the model. When sensitivity of the proxy is high $(\uparrow)$ resilience will be low $(\downarrow)$; similarly, when capacity to respond is high $(\uparrow)$ resilience will be high $(\uparrow)$. For projections, $(\uparrow)$ implies an assumption of increasing and $(\downarrow)$ implies an assumption of decreasing resilience. If specific exposure events, such as a drought or hurricane, occur, resilience will decrease (either an interruption in an increasing variable or a further dip in a decreasing variable). The last column of Table I is discussed in section 5 .

Exposure, that is, the nature and extent of changes that a place's climate is subjected to with regard to variables such as temperature, precipitation, and extreme weather events, is implicitly incorporated. The impact of potential sea level rise is explicitly simulated. The impact of exposure will depend on the development of socioeconomic and environmental capital and is determined by forward-looking adaptation and/or by setbacks from negative impacts from hazards and climate change and variability. 
Table 1. Structure and relationships in the VRIM (including bases of projections)

\begin{tabular}{|c|c|c|c|c|c|}
\hline & Sector & Indicators / data & Proxy for & $\begin{array}{c}\text { Functional } \\
\text { relationships }\end{array}$ & Projected with \\
\hline \multirow{7}{*}{ Sensitivity } & \multirow{2}{*}{$\begin{array}{l}\text { Settlement/ } \\
\text { infrastructu } \\
\text { re } \\
\text { sensitivity }\end{array}$} & $\begin{array}{l}\text { Population at } \\
\text { flood risk from } \\
\text { sea level rise }\end{array}$ & $\begin{array}{l}\text { Potential extent of } \\
\text { disruptions from } \\
\text { sea level rise }\end{array}$ & $\begin{array}{l}\cdot \text { Sensitivity } \uparrow \\
\text { as population at risk } \\
\uparrow \\
-\quad \text { Resilience } \\
\text { over time } \downarrow \text { as } \\
\text { population at risk } \\
\text { increases over time } \\
\text { and sea level rises } \\
\end{array}$ & $\begin{array}{l}\text { Population change } \\
\text { from the SRES } \\
\text { scenarios; sea level } \\
\text { rise from } \\
\text { MiniCAM output }\end{array}$ \\
\hline & & $\begin{array}{l}\text { Population no } \\
\text { access clean } \\
\text { water/sanitation }\end{array}$ & $\begin{array}{l}\text { Access of } \\
\text { population to basic } \\
\text { services to buffer } \\
\text { against climate } \\
\text { variability and } \\
\text { change }\end{array}$ & $\begin{array}{l}-\quad \text { Sensitivity } \uparrow \\
\text { as population with } \\
\text { no access } \uparrow \\
-\quad \text { Resilience } \\
\text { over time } \uparrow \text { as GDP } \\
\text { per capita increases } \\
\text { over time }\end{array}$ & $\begin{array}{l}\text { Indexed safe } \\
\text { drinking water } \\
\text { access and indexed } \\
\text { safe sanitation } \\
\text { access projected } \\
\text { with GDP per } \\
\text { capita changes }\end{array}$ \\
\hline & \multirow[b]{2}{*}{ Food security } & $\begin{array}{l}\text { Cereals production/ } \\
\text { crop land area }\end{array}$ & $\begin{array}{l}\text { Degree of } \\
\text { modernization in the } \\
\text { agriculture sector; } \\
\text { access of farmers to } \\
\text { inputs to buffer against } \\
\text { climate variability and } \\
\text { change }\end{array}$ & $\begin{array}{l}\text { - } \\
\text { as production } \uparrow \\
\text { - } \quad \text { Resilience } \\
\text { over time } \uparrow \text { as } \\
\text { production } \\
\text { technology increases } \\
\text { over time }{ }^{1} \text {. }\end{array}$ & $\begin{array}{l}\text { Crop yield changes } \\
\text { from MiniCAM output }\end{array}$ \\
\hline & & $\begin{array}{l}\text { Protein consumption/ } \\
\text { capita }\end{array}$ & $\begin{array}{l}\text { Access of a population } \\
\text { to agricultural markets } \\
\text { and other mechanisms } \\
\text { (e.g., consumption } \\
\text { shift) for } \\
\text { compensating for } \\
\text { shortfalls in } \\
\text { production }\end{array}$ & $\begin{array}{l}- \text { Sensitivity } \downarrow \\
\text { as consumption } \uparrow \\
\text { - Resilience } \\
\text { over time } \uparrow \text { as protein } \\
\text { consumption } \\
\text { increases and the } \\
\text { undernourishment } \\
\text { index decreases }\end{array}$ & $\begin{array}{l}\text { Indexed nutritional } \\
\text { index }=2 \\
\mathrm{y}=45.711 \mathrm{Ln}(\mathrm{x})- \\
365.88 \\
\mathrm{R}^{2}=0.60\end{array}$ \\
\hline & \multirow[b]{2}{*}{$\begin{array}{l}\text { Ecosystem } \\
\text { sensitivity }\end{array}$} & $\%$ Land irrigated & $\begin{array}{l}\text { Degree of human } \\
\text { intrusion into the } \\
\text { natural landscape }\end{array}$ & $\begin{array}{l}\text { Sensitivity } \uparrow \\
\text { as \% irrigated } \uparrow \\
-\quad \text { Resilience - } \\
\text { over time } \downarrow \text { as \% } \\
\text { agricultural/irrigated } \\
\text { land increases }\end{array}$ & $\begin{array}{l}\text { Land use change from } \\
\text { MiniCAM output }\end{array}$ \\
\hline & & $\begin{array}{l}\text { Fertilizer use/ } \\
\text { cropland area }\end{array}$ & $\begin{array}{l}\text { Nitrogen/phosphorus } \\
\text { loading of ecosystems } \\
\text { and stresses from } \\
\text { pollution }\end{array}$ & $\begin{array}{l}\cdot \quad \text { Sensitivity is } \\
\downarrow \text { if use }<60 \mathrm{~kg} / \mathrm{ha} \text { or } \\
>100 \mathrm{~kg} / \mathrm{ha} ; \uparrow \text { when } \\
\text { use }=>60 \text { and }<100 \\
\mathrm{~kg} / \mathrm{ha} \quad \\
\bullet \quad \text { Resilience } \\
\text { over time } \uparrow \text { when } \\
\text { fertilizer use increases } \\
\text { up to } 60 \mathrm{~kg} / \mathrm{ha} \text { but } \downarrow \\
\text { over time with levels } \\
>160 \mathrm{~kg} / \mathrm{ha}\end{array}$ & $\begin{array}{l}\text { Fertilizer use changes } \\
\text { based on land use } \\
\text { changes from } \\
\text { MiniCAM output }\end{array}$ \\
\hline & $\begin{array}{l}\text { Human health } \\
\text { sensitivity }\end{array}$ & Completed fertility & $\begin{array}{l}\text { Composite of } \\
\text { conditions that affect } \\
\text { human health } \\
\text { including nutrition, } \\
\text { exposure to disease } \\
\text { risks, and access to }\end{array}$ & $\begin{array}{l}-\quad \text { Sensitivity } \downarrow \\
\text { as fertility } \downarrow \\
\text { - Resilience } \\
\text { over time } \uparrow \text { as } \\
\text { birthrates decrease to } \\
\text { a sustainable level }\end{array}$ & $\begin{array}{l}\text { Indexed birth rate }= \\
\mathrm{y}=22.732 \operatorname{Ln}(\mathrm{x})- \\
162.32 \\
\mathrm{R}^{2}=0.34\end{array}$ \\
\hline
\end{tabular}

1 Erosion and desertification may result in the opposite direction which could be tested in a more fine-grained scenario analysis

2 Where $\mathrm{x}$ is GDP per capita 


\begin{tabular}{|c|c|c|c|c|c|}
\hline & & Life expectancy & health services & $\begin{array}{l}\text { - Sensitivity } \downarrow \\
\text { as life expectancy } \uparrow \\
-\quad \text { Resilience - } \\
\text { over time } \uparrow \text { as } \\
\text { (healthy) life } \\
\text { expectancy goes up }\end{array}$ & $\begin{array}{l}\begin{array}{l}\text { Indexed life } \\
\text { expectancy }= \\
\mathrm{y}=47.832 \operatorname{Ln}(\mathrm{x})- \\
393.01 \\
\mathrm{R}^{2}=0.66\end{array}\end{array}$ \\
\hline & \multirow{2}{*}{$\begin{array}{l}\text { Water resource } \\
\text { sensitivity }\end{array}$} & $\begin{array}{l}\text { Renewable supply } \\
\text { and inflow and water } \\
\text { withdrawal }\end{array}$ & $\begin{array}{l}\text { Ratio of water supply } \\
\text { from renewable } \\
\text { resources and } \\
\text { withdrawals to meet } \\
\text { current or projected } \\
\text { needs }\end{array}$ & $\begin{array}{l}\cdot \text { Sensitivity } \uparrow \\
\text { as \% water } \\
\text { withdrawal } \uparrow \\
\cdot \quad \text { Resilience } \\
\text { over time } \downarrow \text { as \% } \\
\text { available fresh water } \\
\text { demand increases }\end{array}$ & $\begin{array}{l}\text { Water demand } \\
\text { changes based on } \\
\text { agricultural production } \\
\text { from MiniCAM output }\end{array}$ \\
\hline & & Precipitation & $\begin{array}{l}\text { Precipitation amount } \\
\text { in } \mathrm{mm}\end{array}$ & $\begin{array}{l}\text { - Sensitivity } \uparrow \\
\text { as \% irrigated land } \uparrow \\
\bullet \quad \text { Resilience } \\
\text { over time } \downarrow \text { as } \\
\text { precipitation } \\
\text { decreases (and } \uparrow \text { with } \\
\text { increasing } \\
\text { precipitation) }\end{array}$ & unchanged \\
\hline \multirow{5}{*}{$\begin{array}{l}\text { Coping \& } \\
\text { Adaptive } \\
\text { Capacity }\end{array}$} & & GDP(market)/ capita & $\begin{array}{l}\text { Distribution of access } \\
\text { to markets, } \\
\text { technology, and other } \\
\text { resources useful for } \\
\text { adaptation }\end{array}$ & $\begin{array}{l}\text { - Coping / } \\
\text { adaptive capacity } \uparrow \text { as } \\
\text { GDP per capita } \uparrow \\
\cdot \quad \text { Resilience } \\
\text { over time } \uparrow \text { as GDP } \\
\text { per capita }- \text { increases } \\
\end{array}$ & $\begin{array}{l}\text { GDP and population } \\
\text { changes from SRES } \\
\text { scenarios }\end{array}$ \\
\hline & $\begin{array}{l}\text { Economic } \\
\text { capacity }\end{array}$ & $\begin{array}{l}\text { Income equity } \\
\text { measure }\end{array}$ & $\begin{array}{l}\text { Realization of the } \\
\text { potential contribution } \\
\text { of all people }\end{array}$ & $\begin{array}{l}\cdot \quad \text { Coping / } \\
\text { adaptive capacity } \uparrow \\
\text { as poverty or inequity } \\
\downarrow \\
-\quad \text { Resilience - } \\
\text { over time } \uparrow \text { as } \\
\text { poverty or inequity } \\
\text { decreases or the } \\
\text { human development } \\
\text { index increases }\end{array}$ & $\begin{array}{l}\text { Unchanged due to lack } \\
\text { of data }\end{array}$ \\
\hline & \multirow[t]{2}{*}{$\begin{array}{l}\text { Human and } \\
\text { civic resources }\end{array}$} & Dependency ratio & $\begin{array}{l}\text { Social and economic } \\
\text { resources available for } \\
\text { adaptation after } \\
\text { meeting other present } \\
\text { needs }\end{array}$ & $\begin{array}{l}\text { - Coping / } \\
\text { adaptive capacity } \downarrow \text { as } \\
\text { dependency } \uparrow \\
\text { - Resilience } \\
\text { over time } \downarrow \text { as the \% } \\
\text { of people dependent } \\
\text { on the working } \\
\text { population increases }\end{array}$ & $\begin{array}{l}\text { Indexed dependency } \\
\text { ratio }= \\
\mathrm{y}=42.087 \mathrm{Ln}(\mathrm{x})- \\
349.31 \\
\mathrm{R}^{2}=0.66\end{array}$ \\
\hline & & Literacy & $\begin{array}{l}\text { Human capital and } \\
\text { adaptability of labor } \\
\text { force }\end{array}$ & $\begin{array}{l}\text { - Coping / } \\
\text { adaptive capacity } \uparrow \text { as } \\
\text { literacy } \uparrow \\
\bullet \quad \text { Resilience } \\
\text { over time } \uparrow \text { as } \\
\text { literacy increases } \\
\end{array}$ & $\begin{array}{l}\text { Indexed literacy rate }= \\
\mathrm{y}=45.09 \operatorname{Ln}(\mathrm{x})- \\
359.56 \\
\mathrm{R}^{2}=0.59\end{array}$ \\
\hline & $\begin{array}{l}\text { Environmental } \\
\text { capacity }\end{array}$ & Population density & $\begin{array}{l}\text { Population pressure } \\
\text { and stresses on } \\
\text { ecosystems }\end{array}$ & $\begin{array}{l}\cdot \text { Coping / } \\
\text { adaptive capacity } \downarrow \text { as } \\
\text { population density } \uparrow \\
\bullet \quad \text { Resilience } \\
\text { over time } \downarrow \text { as } \\
\text { population density } \\
\text { increases }\end{array}$ & $\begin{array}{l}\text { Population changes } \\
\text { from SRES scenarios }\end{array}$ \\
\hline
\end{tabular}




\begin{tabular}{|c|c|c|c|c|c|}
\hline & & $\begin{array}{l}\text { Air pollution/state } \\
\text { area }\end{array}$ & $\begin{array}{l}\text { Air quality and other } \\
\text { stresses on ecosystems }\end{array}$ & $\begin{array}{l}\text { - Coping / } \\
\text { adaptive capacity } \downarrow \text { as } \\
\text { pollution index } \uparrow \\
\bullet \quad \text { Resilience } \\
\text { over time } \downarrow \text { as } \\
\text { pollution increases } \\
\text { and vice versa }\end{array}$ & $\begin{array}{l}\text { Emissions based on } \\
\text { output from MiniCAM }\end{array}$ \\
\hline & & $\%$ Land unmanaged & $\begin{array}{l}\text { Landscape } \\
\text { fragmentation and ease } \\
\text { of ecosystem } \\
\text { migration }\end{array}$ & $\begin{array}{l}\bullet \quad \text { Coping / } \\
\text { adaptive capacity } \uparrow \\
\text { as \% unmanaged land } \\
\uparrow \\
-\quad \text { Resilience } \\
\text { over time } \uparrow \text { as \% } \\
\text { unmanaged land } \\
\text { increases }\end{array}$ & $\begin{array}{l}\text { based on output from } \\
\text { MiniCAM }\end{array}$ \\
\hline
\end{tabular}

Each variable is intended to be understood not only in its denotative sense, but also in a connotative sense as representing a cluster of characteristics relevant to human well-being. For instance, life expectancy is a variable that evokes both overall health and the life chances of individuals. Protein consumption per capita stands not only for a certain level of caloric intake but also for the quality of the diet overall and access of a population to agricultural markets and other mechanisms to compensate for shortfalls in production. Of course, each variable may be critiqued for leaving out what may be important information. For instance, increasing food production may be destined for export, while citizens continue to have inadequate diets. And food sensitivity comprises not just production but also distribution and consumption. This bare-bones representativeness is another reason why an analysis such as this must be extended with more detailed analysis. Issues relating to representativeness, colinearity, and completeness are addressed in Brenkert and Malone (2005).

\subsection{Using the Indicators}

The VRIM's set of quantitative indicators allows for comparisons of regional, country, state or provinces, or smaller localities in terms of their vulnerability and resilience to a current and changing climate (Brenkert and Malone 2005). Moreover, the set points to the differences in sources of resilience among the countries or states compared. Such a comparison can provide the basis for the next-level questions and analyses that will help develop resilience-building policies and programs.

The method for assessing resilience from the set of proxy variables is to first normalize the ranges of data (see Table II), then compute the geometric means of variable values within each sector. The final calculation is to find the geometric means of all eight sectors for each state and for Mexico as a whole. This final indicator value is a comparative measure of the resilience of the states and country. 
Table 2. Range method for indexing proxies (Brenkert and Malone 2005)

\begin{tabular}{|c|c|}
\hline & Range Method \\
\hline Steps in the hierarchy & $\begin{array}{ll}- & \text { geometric mean of proxies }>\text { element } \\
\text { indices } \\
\text { - } \\
\text { geometric means of indices }> \\
\text { sensitivity or coping/adaptive capacity } \\
\text { geometric mean of all indices }> \\
\text { resilience index }\end{array}$ \\
\hline Sensitivity index & kept as positive value \\
\hline Indexing & based on the range of values \\
\hline \multirow{2}{*}{$\begin{array}{l}\text { Determination of the scaled proxy value: alternatives depend on } \\
\text { its value's ranking as "good" or "bad" within the range of proxies } \\
\text { representing the range of geographic entities to be compared }\end{array}$} & Shift $+\frac{100 *(\mathrm{P}-\mathrm{Pmin})}{(\mathrm{Pmax}-\mathrm{Pmin})}$ \\
\hline & Shift $+\frac{100 *(\mathrm{Pmax}-\mathrm{P})}{(\mathrm{Pmax}-\mathrm{Pmin})}$ \\
\hline
\end{tabular}

$\mathrm{P}$ is the country or state's proxy or indicator value

Pmin and Pmax are the minimum and maximum proxy values representing the range of geographic entities to be compared "Shift" is a value that must be used to avoid scores very close to 0 . Results were found to be not very sensitive to any shift value larger than one.

\subsection{Tailoring the Approach to Mexico}

This paper assesses the current resilience of the various Mexican states. We collected base year (2000) data for each of the states (see the Appendix for references) to build our hierarchical model (Figure 1). Within the ecosystem sensitivity sector we substituted the share of irrigated land for the share of managed land used in a previous study (Brenkert and Malone 2005). The response of irrigated land to drought is an interesting case, involving water rights, alternative uses, and perhaps shifts in crops and the extent of irrigation. Precipitation (as a natural source of water availability through replenishment) is now an additional part of the water availability sector; as we are interested in the impacts of drought, changes in precipitation can provide a good basis for varying climate to assess impacts.

\subsection{Baseline Results}

Results of our model run for 2000 are discussed in this section. We first present the ranking of states according to the summation of sector indices (see Figure 2), but in the order that reflects the overall resilience ranking. We then analyze specific pairs of states; including the states rated most and least resilient, to further illustrate our results. The actual values of the resilience indicator are not interesting in themselves; rather we focus on the sources of resilience in comparative analyses.

Overall we find that the states with the greatest resilience to climate change include Jalisco, Sinaloa, Tamaulipas, Nuevo León, the State of Mexico, Quintana Roo and Sonora. By far the least resilient states are located in the south and on the coast: Guerrero, Chiapas and Oaxaca. 
Figure 2. Mexico's states ranked for resilience (summation of sector indices shown)

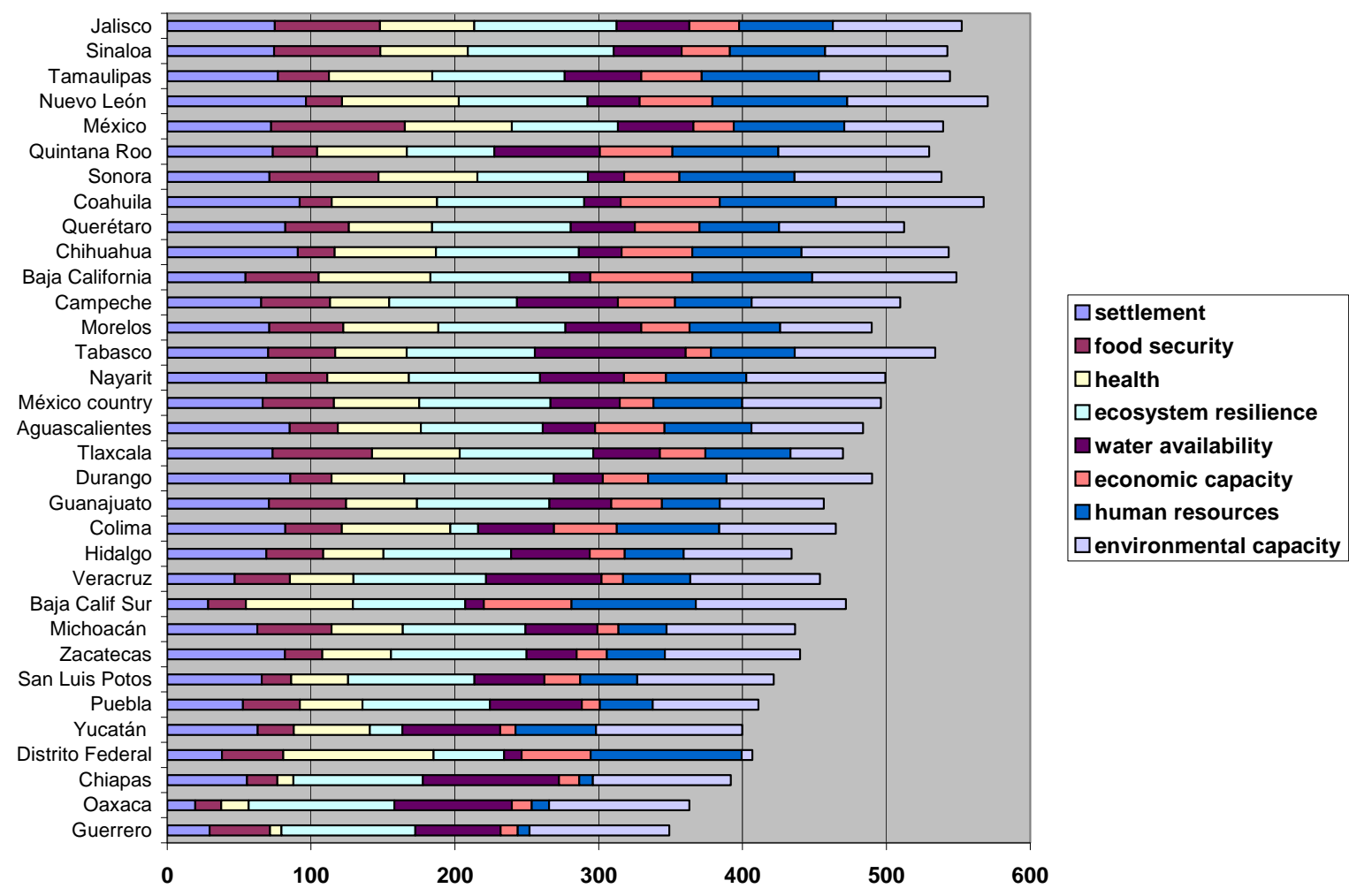

The results show that geographic location, (e.g., coast versus inner or north versus south) is not necessarily a factor determining resilience to climate change. Among the group of states with greater resilience, five of them are coastal (Jalisco, Tamaulipas, Sinaloa, Sonora, and Quintana Roo).

Geographically four are in the north of the country (Nuevo León, Tamaulipas, Sinaloa and Sonora), two in the center (Jalisco and the State of Mexico) and one in the Yucatan Peninsula, in the south (Quintana Roo). On the other hand, several of the less resilient states are on the southern coast (Oaxaca, Guerrero, Chiapas and Yucatan), but there are northern states as well, such as Zacatecas, San Luis Potosi and Baja California Sur.

The sectoral index summation differs in ranking from the resilience indicator ranking, because sectoral indices comprise two or three proxies, and the geometric mean of the sectoral indices result in the resilience index value. For example, the Distrito Federal (DF), even with its high human resource and economic capacity, does not rank at the top because of its lack of ecosystem resilience and low settlement resilience, which is attributable to its poor drinking water quality. Nuevo León ranks high due to its relatively strong human resource and economic capacity in addition to its relatively high environmental capacity, ecosystem resilience, and settlement security, and in spite of its lack of food security. In the least resilient states, economic capacity and human resources are very low, as are settlement security and human health. The transparency of the results aids potential focus on where policy makers might need to build resilience in various states.

Figure 3 shows the "transparency" of the results at a next level. It clearly characterizes the indicators for each state. From here the reasons for low resilience are immediately apparent, like the lack of crop production and water availability in Baja California Sur, or the extreme low precipitation levels in Coahuila, the lack of access to clean sanitation in Oaxaca and the lack of cereal production in Zacatecas. Discussion of these issues can be endless; the information that this analysis can provide helps answer 
questions, such as, what explains differences in resilience to potential climate change across specific states?

Figure 3. Proxy values and their contribution to resilience in Mexican states

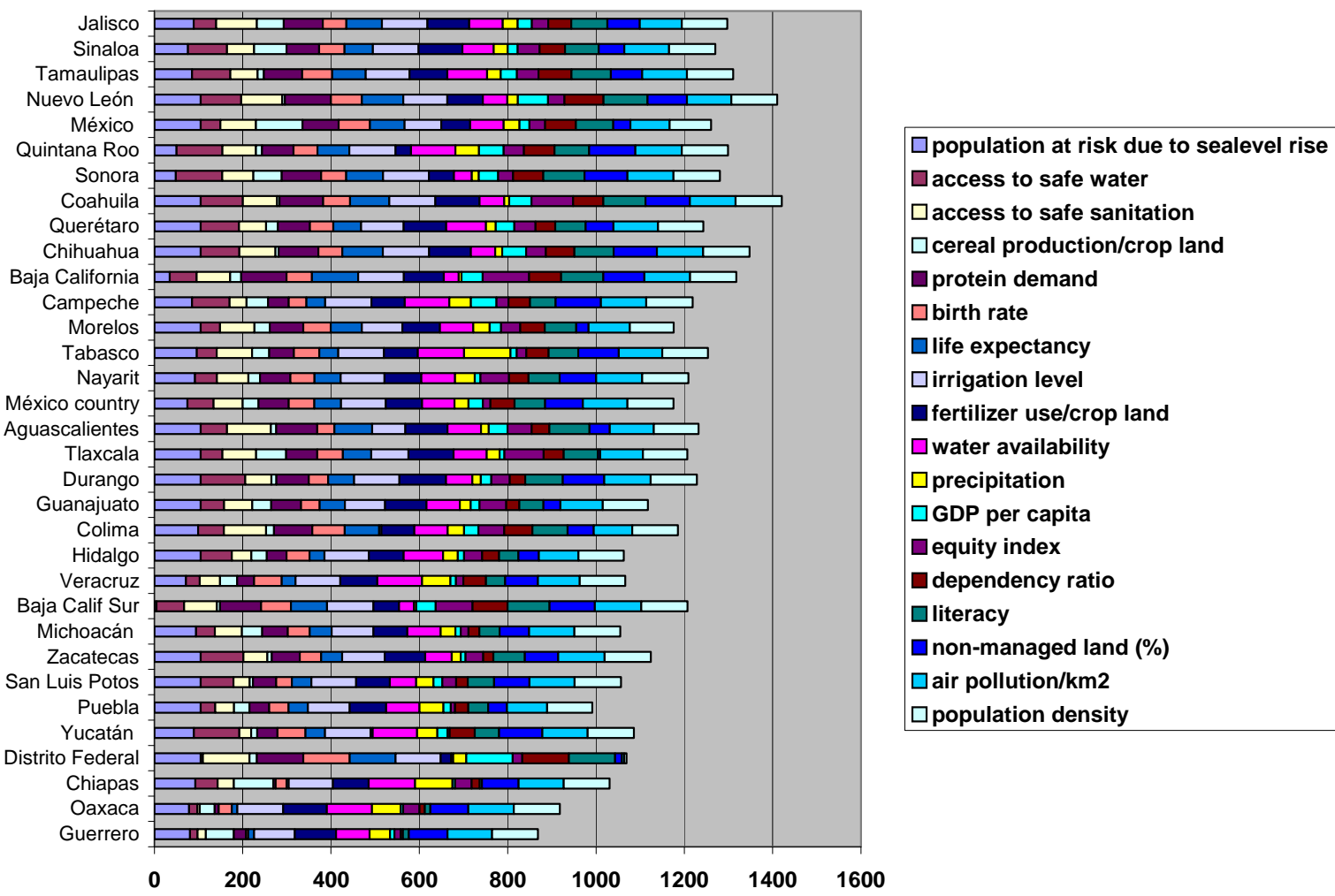

We illustrate these differences with one comparison that may be applied to other states. Nuevo León and Zacatecas are two Northern states that share the same type of natural setting, but they have opposite results in terms of resilience. Nuevo León and Zacatecas (shown in Figure 3) are located in the interior, with similar terrestrial surfaces. Moreover, with comparable (low) rainfall levels, both suffer from droughts and forest fires. Nevertheless, they are substantially different in their resilience to climate change: Nuevo León ranks fourth in this analysis, Zacatecas eighth from the bottom. Their differences are most marked in health, economic capacity, and human resources. In the health sector, values for both life expectancy and birthrate are significantly lower in Zacatecas. Similarly, Zacatecas is much lower - near the bottom of the range for all states - in GDP per capita; but income distribution is about the same, as measured by the Gini coefficient ( 0.4813 for Zacatecas and 0.4873 for Nuevo León [Reyes and Flores 2007]). However, in the human resources sector, Zacatecas has one of the highest dependency ratios of all the states, implying a lower adaptive capacity than Nuevo León; literacy rates are similar for the two states. Nuevo León shows higher resilience in providing safe sanitation but a somewhat lower value in cereal production than Zacatecas.

Analyses and comparisons are often mixed positives and negatives. For example, occasionally, states have similar values for ecosystem resilience or are close in environmental capacity, sometimes due to lower population density and lower pollution; and because they may have a smaller percentage of managed land, leaving more land for buffer purposes. Some states have higher water availability, but significant differences in social and economic factors such as settlement, food security, health, economic capacity, and human resources, leading to a higher adaptive capacity. Some states may be mainly urban, while others may have a large rural component. Thus, examining the component proxy variables in the resilience index provides understanding of the differences in resilience among states. 
This type of analysis allows for a more-or-less detailed diagnosis of the situation of Mexico and each of its states in their capacity to face and adapt to climate change, signaling out those aspects in which they are more sensitive. This helps in planning preventive actions, differentiated by region, to face the possible effects from climate change. It may lead to investment in prevention rather than spending large quantities of resources to remedy a disaster. Thus, this type of analysis supports the elaboration of public policies in the short, medium and long terms in order to face the inescapable phenomenon of climate change.

\subsection{Methods for Projecting Resilience in Mexico}

Extending this baseline of resilience is the next step, since climate change can be expected to make material differences in economic and cultural activities in Mexico, mainly in the medium and long term. Investigating possible future scenarios can provide insights into possible coping and adaptation strategies.

In the projections, the proxies and sectors are again to be understood as representing aspects of societal and environmental well-being. For instance, improvements in the literacy rate indicate that a state is investing in its citizens by developing resilience through greater economic capacity through conditions in the state that, for example, allow the effective conduct of schools. In the same way, improvements in cereal production imply better diets (and, thus, improved health) and better on-farm management. With this understanding, specific values have little meaning, except comparatively.

We used three tools to examine Mexico's resilience in the face of climate change. First, we used the results of the baseline calculations regarding resilience indices made by VRIM as discussed above. Second, we compared (a) the projected short-term rates of socioeconomic change from the BoydIbarrarán computable general equilibrium model (Boyd and Ibarrarán forthcoming) and (b) rates of change from the Intergovernmental Panel on Climate Change's (IPCC's) Special Report on Emissions Scenarios (SRES) (Nakicenovic and Swart 2000), as implemented in the integrated assessment MiniCAM model (Kim et al. 2006). The SRES delayed development scenario (A2 to A1) projected by the MiniCAM integrated assessment model closely matches the projected short-term economic growth as projected by Boyd and Ibarrarán (forthcoming) through 2020 - that is, around $1.9 \%$ per year between 2005 and 2020. GDP per capita increased 7-fold between 1990 and 2095, crop production 5-fold, and population 3-fold. Land-use change was variable, first slightly increasing the amount of managed land, then releasing more land to its natural state over the century. Third, we projected rates of change for variables not available from rates specified in the SRES-based MiniCAM model output, based on current (base year) statistical correlations between (state) variables and GDP per capita. We found significant statistical relationships between various indexed proxies and GDP per capita, and taking advantage of these correlations, extended them as future expectations. Relationships found are not linear; thus, an initial slight increase in GDP per capita might increase economic and adaptive capacity more in poorer states than in more well-off states. The assumptions (see Table 1, last column) allowed us to have available change rates for VRIM variables through the end of the $21^{\text {st }}$ century.

Scenarios of the future should be plausible and consistent, exploring alternative overall pathways and diverse trends within these pathways. In this "delayed growth" SRES scenario (A2 to A1), economic development in Latin America is not extremely vigorous because of continuing institutional setbacks. Because people, ideas, and capital are not very mobile, technology diffuses slowly, resulting in steadystate or moderately increasing international disparities in productivity and income per capita. Fertility rates decline only slowly; the global population is close to 12 billion by 2100, for Mexico between 234 and 260 million (up from 81 million in 1990). Societies give some attention to potential local and regional environmental damage. Vulnerability would be expected to be particularly high in those areas where economic development is delayed and environmental problems are not addressed. 


\subsection{Projection Results}

We calculate the resilience indicator as the geometric mean of the eight sectoral indicators described above, each composed of two or three indexed proxy values at each point in time at 15-year intervals. Deterministic modeling does not take into account the uncertainties of model inputs (i.e., the initial base year proxy values), the uncertainties of the forcing functions (i.e., the changes over time expressed as a scenario description), or the impacts of the model structure. Moreover, in deterministic modeling the importance of parameter contribution (in our case, proxy contribution) to model output can be analyzed only through a decomposition process, which implicitly assumes equal weights of contributing parameters. However, non-equal weights are implicit in the VRIM hierarchy.

Deterministic results may be understood as initial guidance for decision-makers about relatively important elements of a country's or state's vulnerability-resilience to climate change. Along with other, more detailed information, the results can then be the basis for policy or other development decisions in various sectors.

To help analyze the consequences of the assumptions underlying the projections and the impacts of model structure on the uncertainty of the resilience indicator values, we placed the model in a Monte Carlo framework. In a Monte Carlo analysis repeated simulations (calculations) are performed with random combinations of randomly sampled parameters from pre-defined probability distributions. ${ }^{3}$

Results of the Monte Carlo analysis show that over time for each state, the 18 proxy values contribute in a similar fashion to the uncertainty of the resilience indicator as long as each proxy has a coefficient of variation of just $2 \%$. Results also show that the hierarchy of the model matters: the sensitivity sectors explain $5 / 8$ of the total variance of the resilience, and the coping and adaptive capacity the remaining $3 / 8$, reflecting the 5 sectors within sensitivity and the 3 sectors comprising the coping and adaptive capacity. The variance (uncertainty) of the resilience is 100 percent explained in the modeling exercise, indicating that no significant spurious correlations occurred among the sampled proxies.

Scenario descriptions can be used to identify alternative options of pathways into the future (alternative forcing functions for our model.) However, what alternatives in decision-making are available at any one point in time that might lead to different outcomes? An uncertainty analysis addresses this question as follows: the scenario pathways taken by individual proxies can be viewed as proxies of the range of alternatives a decision-maker might have at each point in time. If we sample in the Monte Carlo framework from probability distributions, based on the changes over time calculated in the deterministic solutions, we capture in those ranges the different pathways the proxies might take. We therefore sampled the proxies from distributions representing the 30-year change over time. The upper and lower limits of the triangular distributions we sample from are the values these proxies have either 15 years before or 15 years after the time of calculations; the midpoint of the triangular distribution is established by the deterministically calculated proxy value. The deterministically projected changes differ for each time period. Thus, when changes are large, the variances of the proxies for that point in time are large; when changes are small, the uncertainty or variance from which we sample will be lower.

\footnotetext{
3 In general, varying input parameter best-estimate values $2 \%$ and propagating the variances around the parameters through a model is a way of testing the structure of a model. Mean output values resulting from such a tests are, by definition, very similar to the deterministic output. The effects of model structure can be analyzed by regressing the output values as dependent variables, against the sampled input parameters as independent variables (e.g., Rose et al. 1991). Those parameters explaining most of the variance of the output can thus be identified. Stratified Latin Hypercube sampling of the parameters ensures that each of the input parameters has its total predefined sampling range represented because the procedure consists of dividing the range of each parameter into $\mathrm{N}$ strata of equal marginal probability $1 / \mathrm{N}$ and sampling once from each stratum with $\mathrm{N}=1000$ in our case. Each of the $\mathrm{N}$ samples from each of the parameter values are then combined in a random manner and the indicators calculated a thousand times. This type of sampling avoids spurious correlations among parameters. When parameters are sampled from distributions representing their estimated actual uncertainty, i.e., from a variance larger than the $2 \%$ coefficient of variation, their impacts on the final model outputs change and different parameters contribute more or less to the uncertainty of the outputs depending both on model structure and uncertainties of the parameters. This, again, can be analyzed through ordinary least-squares regression (e.g., Gardner et al. 1983, Moss et al. 2001).
} 
We then calculated the squared Pearson correlation coefficients between the sampled proxies and the calculated state-specific resilience indicators. Proxies with the highest explanatory power can be interpreted as sectors where decision-makers might focus policies to mitigate or adapt to climate change.

Boyd and Ibarrarán suggested that the more substitutable labor, capital, land, and material inputs are, the more resilient an economy will be to the higher costs brought about by a particular extreme climate event such as drought and, by extrapolation, to climate change in general. This would imply, among other things that the more educated and versatile a population is, the better it may adapt. Thus, the better a population is doing in providing access to safe water, sanitation, health care, roads, communication systems and education, the more its labor force can adapt.

The results of our (uncertainty) analyses will address two questions:

1. How does uncertainty of the proxies affect the relative participation of the proxies in the explanation of the uncertainty of the indicators? That is, is the modeling approach informing us regarding which changes in proxy values determine the value of the resilience indicator most at a certain point in time? If so, the type of approach outlined above can illuminate what factors might be more or less important in the future in determining vulnerability and resilience of a location/state/entity.

2. How do changes play out differently in different states? States will change uniquely, depending on investments in infrastructure, their geographic location which determines exposure to hazards, availability of water and quality of soil, if it is resource rich regarding minerals, etc.

We look again at Nuevo León and Zacatecas for consistency purposes. For 2000, Nuevo León ranks near the top in this analysis and belongs to the "heavily populated or industrialized states," Zacatecas ranks near the bottom. Projections indicate that both states become more resilient, with Zacatecas becoming more resilient relative to Nuevo León (Figure 4). As a much poorer state compared to Nuevo León, Zacatecas experiences larger, positive changes over time in dependency ratios than Nuevo León (as based on the assumed convergence as depicted in the correlations). Although both states have a low level of agricultural production, the negative impact of fertilizer use appears earlier (by 2020) in Nuevo León than in Zacatecas (by 2035), probably because Nuevo León begins with a higher level of agricultural production and fertilizer use.

4 http://www.cec.org/files/pdf/ECONOMY/engelect_EN.pdf\#search=\%22hydropower\%20Mexico $\% 20$ states $\% 22$ 
Figure 4. Resilience over time in Nuevo León and Zacatecas
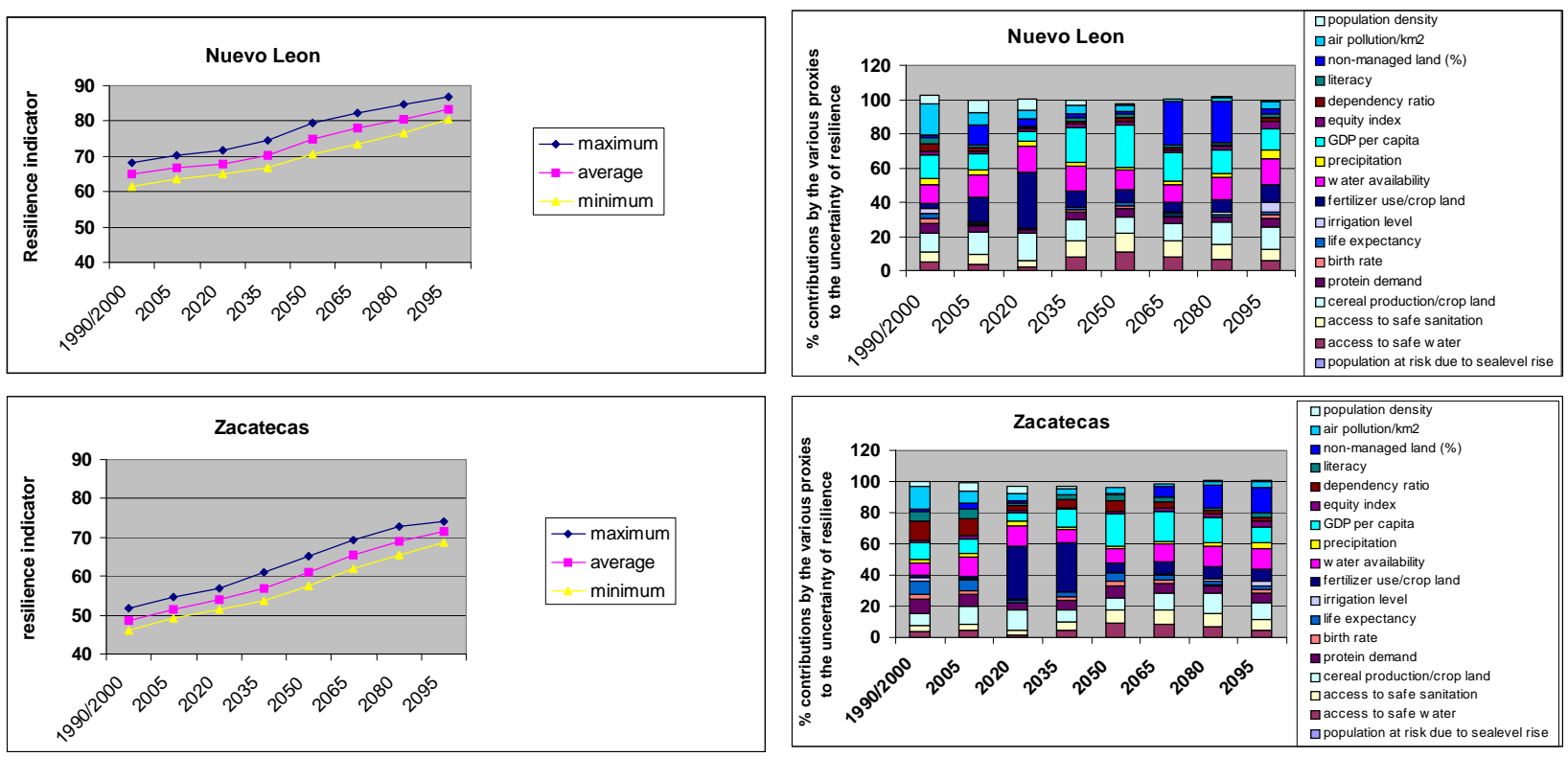

The indicated focus of policy interventions in the different states is very different by 2020 , with over fertilization playing a potentially large role in water pollution in Nuevo León by 2035, but later in Zacatecas. The uncertainty of GDP per capita contributes to the overall resilience uncertainty in both states, but, again, earlier in Nuevo León (2035) and later in Zacatecas (2050). Implications of land management play the greatest role in Nuevo Leon by 2065. Potential policy interventions converge to economic capacity, water availability, and food security by the end of the century.

This same type of analysis can be done for other states. Sometimes differences come from initial conditions and day-to-day practices such as use of fertilizers or overexploitation of water sources or an increase in urbanization. Thus, ecosystem problems may limit the ability of even high human resource capacity to build resilience.

\subsection{The Impacts of Drought on Resilience}

Projections at the national and state level yield a good comparative basis to evaluate the resilience of sub-national levels. One of the main expected impacts from climate change on Mexico is the occurrence of severe droughts. If we can define sectors and proxies that would be affected by drought, how does the assessment of resilience change over time?

Boyd and Ibarrarán (forthcoming) simulated, through a computable general equilibrium model, the impact of a drought that affected mainly agriculture, livestock, forestry, and hydropower generation. They looked at the effects on the overall economy and also simulated the effects of several adaptation strategies in the agricultural and forestry sectors and developed policy implications. They found that the effects of drought vary significantly by sector and had a moderately severe overall impact, while adaptation policies could only make modest changes in the level of economic loss suffered.

The drought impacts as simulated by Boyd and Ibarrarán were only modest for overall GDP. However, drought exposure, through its effect on GDP per capita, also determines changes in the indicator values representing access to clean water and safe sanitation, birth rates, and life expectancy. No changes due 
to drought were simulated for environmental capacity. In the scenario used for projections, environmental capacity is already declining because of land-use changes.

Because of the negative impacts of drought on agricultural income (as part of GDP per capita) and agricultural production, farmers use less fertilizer and thus delay the time when it becomes excessive (i.e., more than $160 \mathrm{~kg} / \mathrm{ha}$ ). These consequences are illustrated for Baja California Sur (Figure 5). Other states, like Tlaxcala, also show delayed intensification of agricultural production and delayed negative effect of excessive fertilizer use when drought has impacted the land. 
Figure 5. Projections of resilience in Baja California Sur with and without drought impact


However, overall the results did not show significant impacts on resilience, despite the known negative effects on people and societies, such as increased poverty, food insecurity, increase in inequality, and loss of livelihoods. At this point modeling would need to be complemented by case studies of droughts and other extreme weather events and/or modeling at a finer scale. 


\subsection{Persistent Concerns}

The comparisons among states and the sources of uncertainty reveal three persistent concerns: economic development, water availability, and food security. Infrastructure development is also a continuing issue. However, industrialization can bring not only prosperity but also environmental degradation (indicated here by air pollution); similarly, increased crop yields can also produce harmful effects, especially on water quality (indicated here by excess fertilizer). The challenge for all state-level governments is to balance social and environmental goals. Analyses such as this one can provide some guidance for evolving emphases that will maintain the balance.

For the projected effects of pollution (timing and magnitude), the two proxies used to indicate air and soil pollution are sulfur- and nitrogen-based emissions and fertilizer use, respectively. Emissions are projected at the same rate for all states, unlike some other proxies that are projected with state-specific rates of change. In most states, the concern about increasing air pollution is overtaken by concern about increasing water pollution from excess fertilizer use. Depending on the intensity of agricultural production, the impact of this type of pollution manifests itself later in some states than in others. We have also seen that only when GDP per capita increases rapidly (after 2035) does this proxy for economic development and well-being participate significantly in the uncertainty of the resilience indicator. Because we projected access to clean water and safe sanitation with GDP per capita, we see this infrastructure development also contributing to the uncertainty of the resilience indicator.

We thus find that those states with initial low GDP per capita have a different initial pattern of proxies contributing to the uncertainty of the resilience indicator, e.g., Oaxaca and Zacatecas vs. Nuevo León and Jalisco. We also find that the negative impact of fertilizer use on overall resilience through its decrease in ecosystem resilience can be delayed if effective measures are taken. Thus, how the agricultural sector responds to the need for intensification is important. 


\subsection{Conclusion}

The models used helped estimate the relative resilience of different states of Mexico from 2000-2095. First, the 2000 values for the resilience index ranked the states with regards to their overall resilience to climate change. Then, through projections using different models, we forecasted how relative resilience would change throughout time given expected economic conditions and particularly due to extreme weather events that will become more common under climate change, i.e., drought.

Drought will affect forestry and hydropower, but its effects will be the greatest in agriculture. Given the low importance of agriculture in national GDP, our modeling results show that drought is of minor importance in determining the values of the resilience indicator, as well as the long-term trend and the relative position of states.

Underneath the model results, which show only modest effects, drought causes societal suffering and disruption, often requiring government assistance. Although these social costs cannot be well identified by aggregate studies, they are real and should be accounted for. Part of the differentiation shown in state-level analyses, points to sectors and areas where more local-level analysis will help decisionmakers plan policy interventions and adaptations to projected climate changes. If modeling is attempted at these smaller scales, factors that reflect potential impacts, such as loss of agricultural land, forced migration, disruption of families, and species death, should be included. The methodology of the VRIM can be applied at any scale and will have the advantage to be able to weigh impacts of climate change and extreme weather events across sectors in a comparative fashion as long as the appropriate proxies can be quantified. 


\subsection{References}

Ávila García, P. (2007), "Las cuencas hidrológicas de México y su vulnerabilidad socio ambiental por el agua", Sustentabilidad y Desarrollo ambiental. Agenda para el Desarrollo 14, 133-161.

Blaikie, P., T. Cannon, I. Davis y B. Wisner (1996), Vulnerabilidad: el Entorno Social, Político y Económico de los Desastres. LA RED/ITDG, Perú. Bogotá: Tercer Mundo Editores.

Boyd, R. and M.E. Ibarrarán (forthcoming), "Extreme Climate Events and Adaptation: An exploratory analysis of drought in Mexico", Environment and Development Economics.

Brenkert, Antoinette L., and Elizabeth L. Malone (2005), "Modeling Vulnerability and Resilience to Climate Change: A Case Study of India and Indian States”, Climatic Change 72, 57-102.

Brooks, N., W.N. Adger, and P.M. Kelly (2005), “The determinants of vulnerability and adaptive capacity at the national level and the implications for adaptation", Global Environmental Change 15, 151-163.

Carstairs, V. and R. Morris (1989), "Deprivation, Mortality and Resource Allocation”, Community Medicine 11, 364-72.

Coombes, M., S. Raybould, C. Wong, and S. Openshaw (1994), "Towards an Index of Deprivation: a review of alternative approaches", in UL Department of the Environment. London: HMSO.

CNA (Comisión Nacional del Agua), (2001), Plan Nacional Hidráulico 2001-2006. México: Comisión Nacional del Agua.

Conde C., and H. Eakin (2003), "Adaptation to Climatic Variability and Change in Tlaxcala, Mexico" en Smith, J.B., R.J.T. Klein and S. Huq (eds.) Climate Change, Adaptive Capacity and Development. Imperial College Press.

Conde, C., R. Ferrer, C. Gay and V. Magaña (1999), "El niño y la agricultura", en Magaña, V. (ed.) Los impactos de El niño en México. México: UNAM.

Conde, C. and C. Gay (1999), "Impacts of climate change and climate variability in Mexico". Acclimations, Issue 8, September-October 1999. U.S. Climate Change Research Program.

http://www.usgcrp.gov/usgcrp/Library/nationalassessment/newsletter/1999.10/Mexico.html

Cutter, S.L., B.J. Boruff, and W.L. Shirley (2003), "Social Vulnerability to Environmental Hazards", Social Science Quarterly, 84 (2), 242-261.

Delft Hydraulics (1993), Sea level rise: a global vulnerability assessment. Tidal Water Division, Rijkswaterstaat, Ministry of Transport, Public Works and Water Management, The Netherlands.

Delgadillo, J., T. Aguilar y D. Rodríguez (2006), Los aspectos económicos y sociales de El Niño. http://www.atmosfera.unam.mx/editorial/libros/el_nino/index.html

Dilley, M., R.S. Chen, U. Deichmann, A.L. Learner-Lam, and M. Arnold, (2005), Natural Disaster Hotspots: A Global Risk Analysis, Disaster Risk Management Series No. 5, World Bank: Washington DC. 
Easterling, D.R., G.A. Meehl, C. Parmesan, S.A. Changnon, T.R. Karl, and L.O. Mearns, (2000), "Climate Extremes: Observations, Modeling, and Impacts", Science 289, 2068-2074.

Emanuel, K., (2005), "Increasing Destructiveness of Tropical Cyclones over the past 30 years", Nature, 436, 686-688.

Folke, C. (2006), "Resilience: the emergence of a perspective for social-ecological analyses", Global Environmental Change, 16, 253-267.

García A., Virginia (coord.) (2005), Construcción Social de Riesgos y el Huracán Paulina, México: CIESAS.

Gardner, R.H., B. Roder and U. Bergstrom (1983), PRISM: A systematic method for determining the effect of parameter uncertainties on model predictions. Nykoping, Sweden: Studsvik Energiteknik AB, report/NW-83/555.

Gay C. (comp.) (2000), México: una visión hacia el siglo XXI. El cambio climático en México. Resultados de los estudios de vulnerabilidad del país. México: Instituto Nacional de Ecología, Secretaría de Medio Ambiente y Recursos Naturales, Universidad Nacional Autónoma de México, and U.S. Country Studies Program.

Gay, C. (ed.) (2003), México: una visión hacia el siglo XXI. El Cambio Climático en México, SEMARNAT and UNAM.

Gay, C., F. Estrada, C. Conde, and H. Eakin (2004), "Impactos potenciales del cambio climático en la agricultura: Escenarios de producción de café para el 2050 en Veracruz (México)" in García, J. C., C. D. Liaño, D. F. Rasilla, P. Fernández de Arróyabe, C. Garmendia (eds.) (2004), El clima entre el mar y la montaña. Asociación Española de Climatología y Universidad de Cantabria, Serie A. no. 4, Santander.

Holling, C.S. 1973. "Resilience and stability of ecological systems." Annual Review of Entomology 6, $163-182$.

Ibarrarán, M.E., M. Ruth, S. Ahmad y M. London (forthcoming), "Climate Change and Natural Disasters: Macroeconomic Performance and Distributional Impacts", Environment, Development and Sustainability.

Ibarrarán, M.E. and R. Boyd, (2006), Hacia el Futuro: Energy, Economics and the Environment in 21st Century Mexico. The Netherlands: Springer.

INEGI (1996), Conteo de Población y Vivienda 95. Resultados Preliminares. México: INEGI

Intergovernmental Panel on Climate Change (IPCC) 2001. Third Assessment Report-Climate Change 2001. Geneva, Switzerland.

Kaufmann, R.K., B. Davidsdottir, S. Garnham and P. Pauly (1998), "The determinants of atmospheric $\mathrm{SO}_{2}$ concentrations: reconsidering the environmental Kuznets curve", Ecological Economics 25(2), 209220.

Kim, S.H., J. Edmonds, J. Lurz, S.J. Smith, and M. Wise (2006), "The Objects Framework for Integrated Assessment", The Energy Journal, 63-91. 
Liverman, D.M. (1990), "Drought and Agriculture in Mexico: The case of Sonora and Puebla in 1970," Annals of the Association of American Geographers 80(1), 49-72.

Liverman, D.M. (1994), "Vulnerability to Global Environmental Change," in S. Cutter, (ed.), Environmental Risks and Hazards. U.S.A.: Prentice Hall.

Luers, A.L., D.B. Lobell, L.S. Sklar, C.L. Addams and P.A. Matson. (2003), “A method for quantifying vulnerability, applied to the agricultural system of the Yaqui Valley, Mexico", Global Environmental Change 13, 255-267.

Magrin, G., C. Gay García, D. Cruz Choque, J.C. Giménez, A.R. Moreno, G.J. Nagy, C. Nobre and A. Villamizar (2007), Latin America. Climate Change 2007: Impacts, Adaptation and Vulnerability. Contribution of Working Group II to the Fourth Assessment Report of the Intergovernmental Panel on Climate Change, M.L. Parry, O.F. Canziani, J.P. Palutikof, P.J. van der Linden and C.E. Hanson, (eds.). Cambridge: Cambridge University Press, UK, 581-615.

MacDonald, G. M., D.W. Stahle, J. Villanueva Diaz, N. Beer, S. J. Busby, J. Cerano-Paredes, J.E. Cole, E.R. Cook, G. Endfield, G. Gutierrez-Garcia, B. Hall, V. Magana, D. M. Meko, M. MéndezPérez, D. J. Sauchyn, E. Watson, and C. A. Woodhouse, (2008), Climate Warming and 21st-Century Drought in Southwestern North America, Eos Trans. AGU, 89(9).

Malone, E.L. and A.L. Brenkert [in press]. "Vulnerability, sensitivity, and coping/adaptive capacity worldwide", in The Distributional Effects of Climate Change and Disasters: Concepts and Cases, M. Ruth and M.E. Ibarraran (eds.), Edward Elgar Publishing.

Malone, Elizabeth L. and Antoinette L. Brenkert (2008), "Uncertainty in Resilience to Climate Change in India and Indian States", Climatic Change 91, 451-476.

McCarthy, J.J., O.F. Canziani, N.A. Leary, D.J. Dokken and K.S. White (eds) (2001), Climate change 2001: impacts, adaptation, and vulnerability. Cambridge: Cambridge University Press.

Molina, M. and L. T. Molina, (eds.) (2002), Air Quality in the Mexico Megacity: An Integrated Assessment. Alliance for Global Sustainability Bookseries. Kluwer Academic Publishers.

Moss, R.H., A.L. Brenkert and E.L. Malone (2001), "Vulnerability to Climate Change: A quantitative Approach”. PNNL-SA-33642. Washington DC: Pacific Northwest National Laboratory.

Nakicenovic, N. and R. Swart (2000), Special Report on Emissions Scenarios (SRES). Cambridge: Cambridge University Press.

Parry, M., O. Canziani and J. Palutikof (2008), Climate Change 2007: Impacts, Adaptation and Vulnerability. Workgroup II Contribution to the Fourth Assessment Report of the Intergovernmental Panel on Climate Change. Cambridge University Press.

Parson EA and K Fisher-Vanden 1997, "Integrated assessment models of global climate change", Annual Review of Energy and the Environment 22, 589-628.

Pratschke, J. and T. Haase (2000), "Structures of Disadvantage: Spatial and Theoretical Aspects of Index Construction", Fifth International Conference on Logic and Methodology, Cologne, Germany, Oct 3-6, 2000.

Rasmussen, Tobias N. (2004), "Macroeconomic implications of natural disasters in the Caribbean". IMF Working Paper WP/04/224. 
Reyes, M. y R. Flores (2007). Causas y persistencias de la desigualdad en México 1984-2004. Documento de trabajo, Campo Estratégico de Pobreza y Exclusión (CEAPE). Universidad Iberoamericana Puebla, México.

Rose, K.A., E.P. Smith, R.H. Gardner, A.L. Brenkert and S.M. Bartell (1991), "Parameter sensitivities, Monte Carlo filtering, and model forecasting under uncertainty", Journal of Forecasting 10, 117-133.

Sanchez-Rodríguez, R. (2002), "Sustentabilidad urbana, descentralización y gestión local", en La transición hacia el desarrollo sustentable: perspectivas de América Latina y el Caribe, Enrique Leff (coord.), Secretaría de Recursos Naturales y Medio Ambiente, Instituto Nacional de Ecología, Universidad Autónoma Metropolitana, Programa de las Naciones Unidas para el Medio Ambiente.

Sánchez-Rodríguez, R., K. C.Seto, D. Simon, W. D. Solecki, F. Kraas and G. Laumann, 2005. "Science plan urbanization and global environmental change". International Human Dimensions Programme on Global Environmental Change, Report No. 15.

Sánchez-Rodriguez, Roberto (2002), "Cities and Global Environmental Change: Challenges and Opportunities for a Human Dimension Perspective". Newsletter of the International Human Dimensions Programme on Global Environmental Change, Number 3/2002.

Satterthwaite, D., S. Huq, M. Pelling, H. Reid and P. Romero Lankao (2007), "Adapting to Climate Change in Urban Areas: The possibilities and constraints in low- and middle-income nations". Human Settlements Discussion Paper Series.

SEMARNAP (1997), México: Primera Comunicación Nacional ante la Convención Marco de las Naciones Unidas sobre el Cambio Climático, Enkidu Editores. www.semarnap.gob.mx

Townsend, P., P. Phillimore, and A. Beattie (1988), Health and Deprivation: Inequality and the North. London: Croom Helm.

Trenberth, K.E. (2005), “Uncertainty in hurricanes and global warming”, Science 308, 1036-1039.

Vera Cortés, V. (2005), "Vulnerabilidad social y expresiones del desastre en el distrito de Pochutla, Oaxaca", en La Construcción Social de Riesgos y el Huracán Paulina, México: Centro de Investigaciones y Estudios Superiores en Antropología Social (CIESAS).

Watson, R.T., M.C. Zinyowera and R.H. Moss (1996), Climate change 1995: impacts, adaptations and mitigation of climate change: scientific-technical analyses. Cambridge: Cambridge University Press.

Watson, R.T., M.C. Zinyowera, R.H. Moss and D.J. Dokken (1998), The regional impacts of climate change, an assessment of vulnerability. A special report of IPCC working group II, Cambridge University Press.

Webster, P.J, G.J Holland, J.A. Curry, and H.R. Chang (2005), "Changes in tropical cyclone number, duration, and intensity in a warming environment", Science vol. 309, no. 5742, 1844-1846.

Zizumbo, D. (2003), "Impacto ecológico del huracán Isidoro a su paso por la porción norte de la península de Yucatán”, Revista de la Universidad Autónoma de Yucatán 18, 3-9. 
Appendix. Sources for the indicators used in the VRIM México study

\begin{tabular}{|c|c|c|c|c|}
\hline & Sector & Indicator / Data & Characteristics of the indicator for Mexico & Sources: \\
\hline \multirow[t]{9}{*}{ Sensitivity } & \multirow[t]{3}{*}{ Infrastructure } & $\begin{array}{l}\text { Population at risk of } \\
\text { sea level rise }\end{array}$ & $\begin{array}{l}\text { It reflects the population that would be affected by } \\
\text { increments in the sea level }\end{array}$ & - $\quad$ DELFT, UN. \\
\hline & & $\begin{array}{l}\text { Population without access to quality } \\
\text { drinking water }\end{array}$ & $\begin{array}{l}\text { Own calculation using: } \\
\text { - share of population with access to potable water } \\
\text { • water quality according to BOD in administrative hydrologic } \\
\text { regions }\end{array}$ & $\begin{array}{l}\text { - } \quad \text { INEGI, XII Censo General de Población y } \\
\text { Vivienda, 2000 } \\
\text { - SEMARNAT, Comisión Nacional del Agua. } \\
\text { Situación del Subsector agua potable, } \\
\text { alcantarillado y saneamiento, CNA, México, } \\
2001 \\
\text { Estadísticas del Agua en México, Edición 005, } \\
\text { Gerencia Saneamiento y Cal. del Agua SGT } \\
\text { CNA } \\
\end{array}$ \\
\hline & & $\begin{array}{l}\text { Population without access to drainage } \\
\text { and sewage }\end{array}$ & $\begin{array}{l}\text { Own calculation using: } \\
\text { - share of population with access to sewage } \\
\text { • share of population with access to drainage }\end{array}$ & $\begin{array}{l}\text { - } \quad \text { SEMARNAT, Comisión Nal del Agua.Situación del } \\
\text { Subsector de Agua Potable, Alcantarillado y } \\
\text { Saneamiento. } \\
\text { - } \quad \text { INEGI, XII Censo de Población y Vivienda del } \\
2000 . \\
\end{array}$ \\
\hline & Food Security & Cereal production & $\begin{array}{l}\text { Own calculate using: } \\
\text { - production of cereal, includes amaranto, rice, oat, rye, } \\
\text { corn, wheat and sorghum } \\
\text { - agricultural land use } \\
\end{array}$ & $\begin{array}{ll}\text { - } & \text { SAGARPA, Servicio de Información } \\
\text { Estadística, Agroalimentaria y Pesquera } \\
\text { - } \quad \text { Inventario Nacional de Emisiones de México } \\
\text { 999, Borrador Final. Nov. 2005. } \\
\end{array}$ \\
\hline & \multirow[t]{2}{*}{ Health } & Global fertility rate & $\begin{array}{l}\text { Average number of children that a woman expects to have } \\
\text { at end of her reproductive life cycle according to the fertility } \\
\text { rates by age group observed in a given year. }\end{array}$ & $\begin{array}{l}\text { - } \quad \text { CONAPO, } w \text { ww.conapo.gob.mx/00cifras/00 } \\
\text { indicadores/30.xls }\end{array}$ \\
\hline & & Life expectancy at birth & $\begin{array}{l}\text { Average of years that a person expects to live at the } \\
\text { Moment of his birth on the base of the mortality rates by age } \\
\text { for a specific year. }\end{array}$ & $\begin{array}{l}\text { - } \quad \text { CONAPO, }, \text { www.conapo.gob.mx/00cifras/00 } \\
\text { indicadores/30.xls }\end{array}$ \\
\hline & Ecosystem & Share of irrigated land & Degree of human intrusion into the natural landscape & $\begin{array}{l}\text { Análisis de Sequías Volumen I, UNAM. } \\
\text { Principales Usos del Suelo por Entidad } \\
\text { Federativa, INEGI, 1992; SARH, 1992, } 1994 .\end{array}$ \\
\hline & Fertilizer use & $\begin{array}{l}\text { Own calculation: } \\
\text { • Nitrogen, } \mathrm{N} \\
\cdot \text { Phosphorous, } \mathrm{P}\end{array}$ & $\begin{array}{l}\text { Nitrogen/phosphorus loading of ecosystems and stresses from } \\
\text { pollution }\end{array}$ & $\begin{array}{l}\text { - } \quad \text { Ojeda, D y E. Ojeda T., "Suelos Cultivados de } \\
\text { La República Mexicana, Contenido Medio de } \\
\text { Nutrimentos Minerales Aprovechables", } \\
\text { Universidad Autónoma de Chapingo, México } \\
1996 .\end{array}$ \\
\hline & $\begin{array}{l}\text { Water } \\
\text { Resources }\end{array}$ & $\begin{array}{l}\text { Degree of pressure } \\
\text { Rain average }\end{array}$ & $\begin{array}{l}\text { Own calculation. The degree of pressure is defined as the } \\
\text { relation among the total volume of concessioned water and } \\
\text { average availability of water. We assign this according to } \\
\text { the administrative hydrologic region of the ANC to which the } \\
\text { majority of the state belongs. }\end{array}$ & $\begin{array}{l}\text { - } \\
\text { MEMARNARAT, Estadísticas del Agua en } \\
\text { Saneamiento y Calidad del Agua. SGT. CNA } \\
\text { Subdirección General de Programación. }\end{array}$ \\
\hline
\end{tabular}




\begin{tabular}{|c|c|c|c|c|}
\hline \multirow[t]{6}{*}{$\begin{array}{l}\text { Adaptive } \\
\text { and } \\
\text { coping } \\
\text { capacity }\end{array}$} & \multirow[t]{2}{*}{$\begin{array}{l}\text { Economic } \\
\text { Capacity }\end{array}$} & $\begin{array}{l}\text { Gross domestic } \\
\text { product, GDP per } \\
\text { capita }\end{array}$ & $\begin{array}{l}\text { Own calculation: } \\
\text { - Gross domestic product } \\
\text { - Total population }\end{array}$ & $\begin{array}{l}\text { INEGI, Sistema de Cuentas Nacionales de } \\
\text { México. A precios de 1993, valores absolutos, } \\
\text { por gran división de actividad económica. } \\
\text { Unidad de medida: Miles de pesos a precios } \\
\text { de 1993. } \\
\text { INEGI, XII Censo General de Población y } \\
\text { Vivienda, } \\
\text { 2000, Tabulados Básicos. Aguascalientes, } \\
\text { 2001 }\end{array}$ \\
\hline & & Gini Coefficient & Indictor of income distribution. & - $\quad$ Reyes and Flores 2007 \\
\hline & \multirow[t]{2}{*}{$\begin{array}{l}\text { Civic and } \\
\text { Human } \\
\text { Resources }\end{array}$} & Dependency ratio & $\begin{array}{l}\text { Number of dependents (people from } 0 \text { to } 14 \text { and } 65 \text { and } \\
\text { more years old) by each } 100 \text { independent (people from } 15 \\
\text { to } 64 \text { years old) }\end{array}$ & $\begin{array}{l}\text { INEGI. XII Censo de Población y Vivienda } \\
\text { 2000, www.inegi.gob.mx }\end{array}$ \\
\hline & & Schooling index & Own calculation, average of literacy and years of schooling & $\begin{array}{l}\text { - INEGI, XII Censo de Población y Vivienda, } \\
\text { 2000. Tabulados Básicos, } 2001\end{array}$ \\
\hline & \multirow[t]{2}{*}{$\begin{array}{l}\text { Environmental } \\
\text { capacity }\end{array}$} & $\begin{array}{l}\text { Share of non- } \\
\text { managed land }\end{array}$ & $\begin{array}{l}\text { Own calculation: } \\
\text { - Deserts } \\
\text { - Areas without apparent vegetation } \\
\text { - Disturbed Areas }\end{array}$ & $\begin{array}{l}\text { INEGI, 1992, SARH, 1992, 1994. Análisis de } \\
\text { la Sequía en México, Volumen I, UNAM }\end{array}$ \\
\hline & & $\begin{array}{l}\text { Emissions } \\
\text { by surface area }\end{array}$ & $\begin{array}{l}\text { It includes emissions of fixed self-propelled, mobile and } \\
\text { Natural sources, divided over total land area for each state }\end{array}$ & - $\quad$ Inventario Nacional de Emisiones de México 1999. \\
\hline
\end{tabular}

